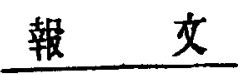

\title{
硝酸銀を含む綬衝溶液によってぬらされた口紙上におけるチオ尿素, グアニジン，ならびにその誘導体の電気泳動*
}

\section{Electrophoresis of Thiourea, Guanidine, and Their Derivatives on the Paper Wetted by Buffer Solution Containing Silver Nitrate}

$$
\begin{aligned}
& \text { 鈴木伸**，高橋涉** } \\
& \text { Shin SuzukI， Wataru TAKAHASHI }
\end{aligned}
$$

1 緒

論

筆者らは写真用添加剤の研究に関しその口紙電気泳動 を武み，第 1 報》ではその泳動の各 $\mathrm{pH}$ による影響につ いて報告した。これは各 $\mathrm{pH}$ の緩衝溶液で浸された口 紙上で写真用添加剤を泳動させて行なったものである。 その結果チオ尿素やグアニジン系化合物は酸性で予期し たでとく陽イオン的挙動をとるてとを確め得た。これは Aを添加㓮分子とすると

$$
\mathrm{A} l+m \mathrm{H}^{+} \rightarrow \mathrm{A}_{l} \mathrm{H}^{+}{ }_{m}(l, m \text { は整数 })
$$

のごとき反応によって $\mathrm{A}_{l} \mathrm{H}_{m}{ }^{+}$なる錯イオンを生成する ためであると解した。

ここではさらに銀イオンの存在下でこの㑯向がどのよ うに影響を受けるかをみようとした。すなわち上と類似 の反応により $\mathrm{A}_{l} \mathrm{Ag}^{+}{ }_{m}$ または $\mathrm{A}_{l} \mathrm{H}^{+}{ }_{m} \mathrm{Ag}^{+}{ }_{n}(n$ は整数)の でとき錯イオンが生成されるかどうかをみようとした。

本報で扱った試料仙于才尿素 (I)，チ才セミカルバシ ド (II)，p-サクシノイルアミノベンッアルデヒド-3-チ オセミカルバゾン (III)，グアニジン (IV)，およびベン ザルアセトングアニルヒドラゾン（V）の五種である. これらの試料(前報1 にも述べたように $\mathrm{X}=\mathrm{C}<\mathrm{N} \mathrm{R} \mathrm{R}_{\mathbf{k}} \mathrm{R}_{\mathbf{1}}$ 型構造を持つものでこの構造中の $\mathrm{X} や \mathrm{R}_{\mathbf{i}}, \mathrm{R}_{\mathbf{j}}, \mathrm{R}_{\mathbf{k}}, \mathrm{R}_{1}$ などの基の変化が $\mathrm{H}^{+}$や $\mathrm{Ag}^{+}$の親和性, 口紙に対する 吸着性などにどうひびくかに興味を持たれているもので ある。

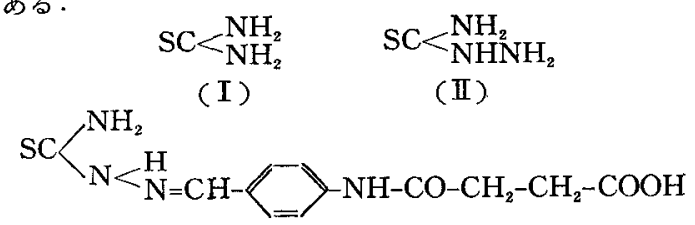

(III)

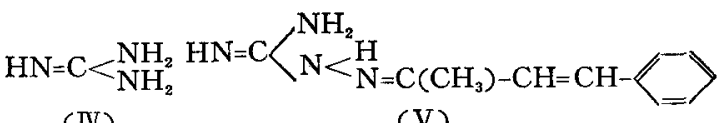

$$
\text { (IV) }
$$

* 写真用添加剂の口紙電気泳動に関才る研究(第 2 報) Paper Electrophoresis of Photographic Addition Agents (Part 2)

** 東京大学工学部 (東京都文京区本富士町 1 )

\section{2 实 験 装 置}

本研究に使用せる口紙電気泳動装置の概要を図 1 に示 す.

通電中電極付近で電解反応が起てっても電極室と口紙 媒帯液を入れる容器とは塩橋 (寒天橋) で分離している のでその影響は無視される．また通電中のジュール熱に よる口紙上の媒帯液の蒸発はカパーガラスによって防止 できる。

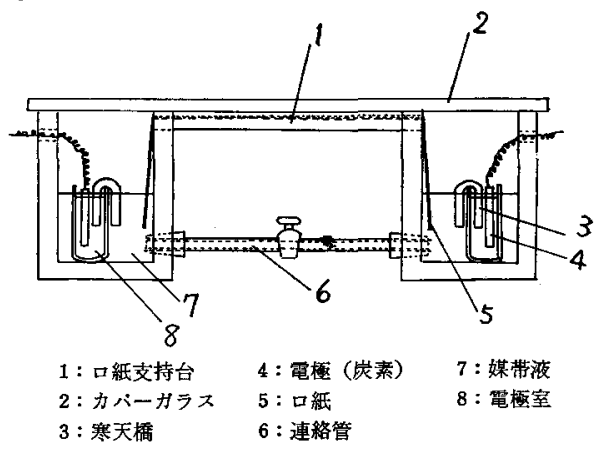

図 1 口紙電気泳動装置

\section{3 実 験 条 件}

口紙はすへて東洋口紙 No. $51\left(40 \times 2 \mathrm{~cm}^{2}\right)$ を使用し た. 電圧は $500 \mathrm{~V}$ とし，定電圧で行なった。その時の電 流は口紙一本あたり最高 $2 \mathrm{~mA}$ であった。電压印加時 間は 30 80 分まで武料の易動度により適当に選んだ。 電気泳動を行なう前にあらかじめ 口紙は所定の $\mathrm{pH}(3$ ９）に緩衝された $10^{-2} \sim 10^{-5} \mathrm{M}$ の硝酸溶液でぬらし ておき，武料溶液はすべて $0.1 \mathrm{M}$ の嶩度で使用しその 約 $0.006 \mathrm{~m} l$ をとって䋛衝溶液と硝酸銀溶液でぬらされ ている口紙上の中央に 線状に塗布し通電した，温度は 15 20ㄷ である.

\section{4 硝酸銀を含む緩㣫溶液の調製}

硝酸銀を合む緩衝溶液を調製するため，まず各 $\mathrm{pH} 5$ 、 の緩衝溶液をつくる，緩衝溶液は前報己ほぼ同要領によ りコリジン溶液と酥酸溶液との適量混合に上り， $\mathrm{pH} 3$ 、 
7,9 のものを調彆，またピりジン溶液と酭酸溶液との適 量混合により pH 5 のものを調製した。

目的とする媒帯液はこれら各緩衝溶液に $0.1 M$ また は $0.01 M$ 硝酸銀溶液を計算量添加して $10^{-2} M \sim 10^{-5}$ $M$ の硝酸銀を含む緩徱溶液を調製した。

\section{5 色花の調製ならびに発色法}

口紙電気泳動後用いる発色液は次のように調製した。

(a) チオ尿素，チオセミカルバシド，Pーサクシノィ ルアミノベンツ-3-チオセミカルバゾン用発色液

$0.1 M \exists$ 素溶液 $5 \mathrm{~m} l$ と $0.87 M$ アシ化ナトリウ 么溶液 $50 \mathrm{~m} l$ を混合する。との液を口紙上に散布する と試料の存在するところは無色となり，試料の存在せぬ ところはカッ色となる。

(b) グアニジン，ベンザルアセトングアニルヒドラ ゾン用発色液

$10 \%$ 水酸化ナトリウム溶液， $10 \%$ ニトロプルシドナ トリウム溶液，1096 赤血塩溶液をそれぞれ同量づつ混 合する. 30 分間放置した後 その溶液の 3 倍の水之 4 倍 のアセトンを加えてこれをうすめる．との液を口紙上に 散布すると試料の存在するところは赤橙色あるいは赤紫 色となり，試料の存在せぬとしろは薄緑色となる，

\section{6 実 験 結 果}

電気泳動終了後，武料の存在するところを発色液にて 確認し，その移動した最大および最小距離をものきしで

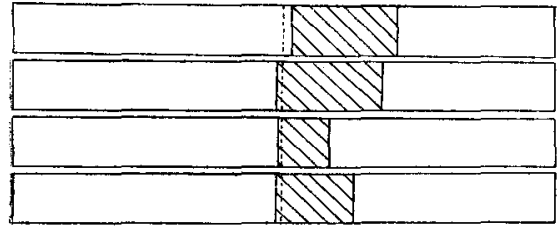
(a) (b) (c) (d)

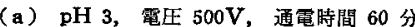

(b) $\mathrm{pH} 5$, 電丝 $500 \mathrm{~V}$, 通電時間 60 分

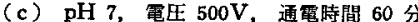

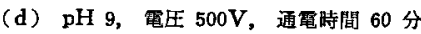

図 2 千才层素の口紙電気泳動のpH変化 $(\mathrm{pAg} 3)$

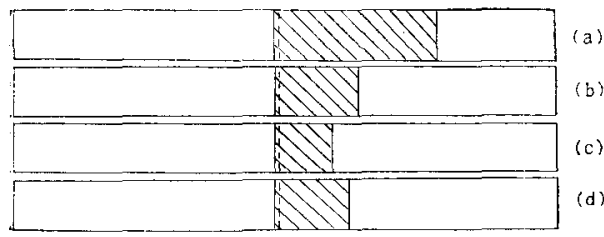

(a) $\mathrm{pH} 3$, 電压 $500 \mathrm{~V}$, 通笔時哃 69 分

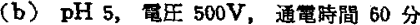

(c) $\mathrm{pH} \mathrm{7,} 500 \mathrm{~V}$, 通電時間 60 分

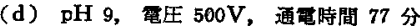

図 3 チオセミカルバジドの口紙電気泳動の $\mathrm{pH}$ 変化 $(\mathrm{pAg} 3)$
測り，その平均值を移動距離とした

泳動度 $v\left(\mathrm{~cm}^{2} / \mathrm{sec} \cdot v o l t\right)$ 浪印加電在 $V$ (volt), 印加 時間 $t(\mathrm{sec})$ より次式に基づいて計算した。また口紙の 長さ $30 \mathrm{~cm}$ によって等分雪圧降下があるものとする。

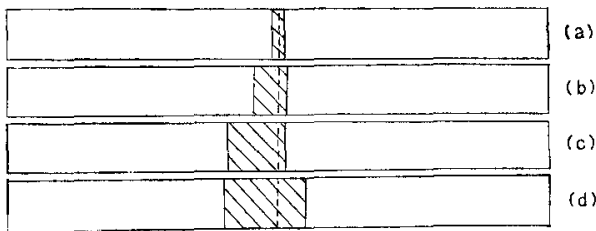

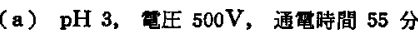

(b) $\mathrm{pH} \mathrm{5,} 500 \mathrm{~V}$, 通電時間 85 分

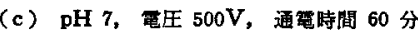

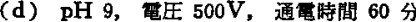

図 4 がサクシノイルアミノベンッオルデヒド-3チオセミカルバゾンの口紙電気泳動の $\mathrm{pH}$ 変化 $(\mathrm{pAg} 3)$

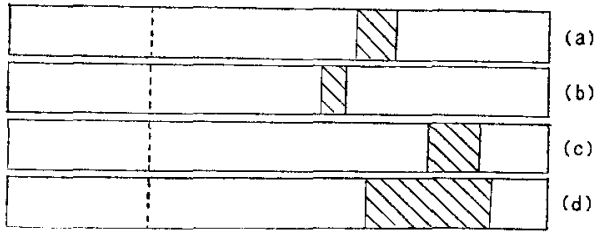

(a) $\mathrm{pH} \mathrm{3}$, 秏圧 $500 \mathrm{~V}$ ，通電時間 38 分

(b) $\mathrm{pH} 5$, 電圧 $500 \mathrm{~V}$, 通箅封間 42 分

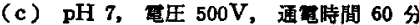

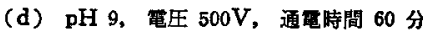

図 5 グフニジンの紙電気泳動の $\mathrm{pH}$ 変化 (pAg 3)

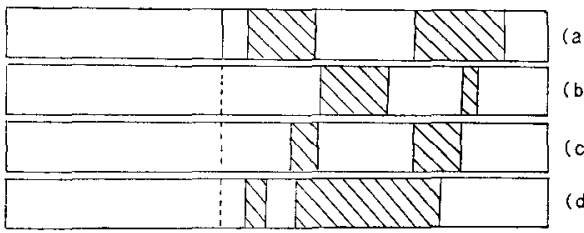

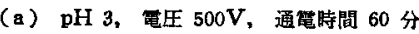

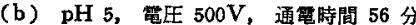

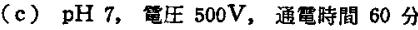

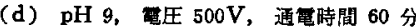

図 6 ベソザルナセトングアニルヒドラゾンの 口紙電気泳動の $\mathrm{pH}$ 变化 $(\mathrm{pAg} 3)$

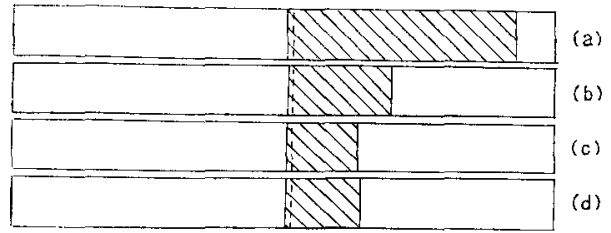

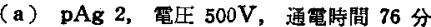

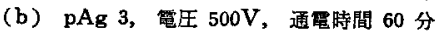

(c) $\mathrm{pAg} \mathrm{4,} 500 \mathrm{~V}$, 通電時間 60 分

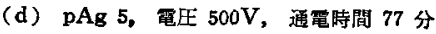

図 7 チオ尿素の口紙電気泳動の $\mathrm{pAg}$ 変化 (pH 5) 


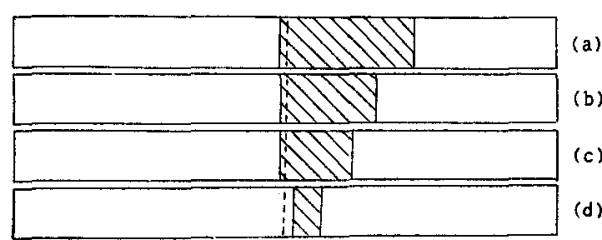

(a) $\mathrm{pAg}_{2}$, 電圧 $500 \mathrm{~V}$, 通電時間 63 分

(b) $\mathrm{pAg} \mathrm{3}$ ，電生 $500 \mathrm{~V}$, 通䉓時間 60 分

(c) $\mathrm{pAg} 4$, 電王 $500 \mathrm{~V}$, 通電時間 63 分

(d) $\mathrm{pAg} 5$, 電圧 $500 \mathrm{~V}$, 通笔時間 73 分

図 8 チオ ミカルバジドの口紙電気泳動の $\mathrm{pAg}$ 変化 $(\mathrm{pH} 5)$

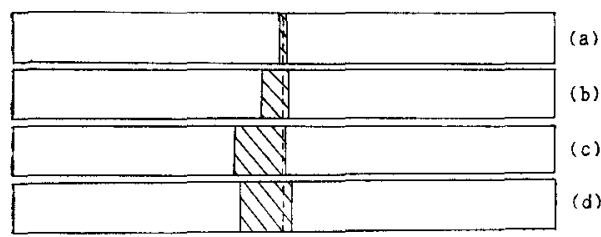

(a) $\mathrm{pAg} 2$, 電压 $500 \mathrm{~V}$, 通奄時間 65 分

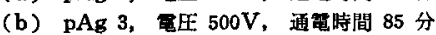

(c) $\mathrm{pAg} 4$, 電压 $500 \mathrm{~V}$, 通䉓時間 60 分

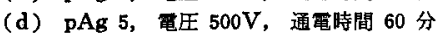

図 9 p-サクシノイルフミノベンツフルデヒド ー3ーチオ七ミカルバゾンのロ紙電気泳動の $\mathrm{pAg}$ 変化 (pH 5)

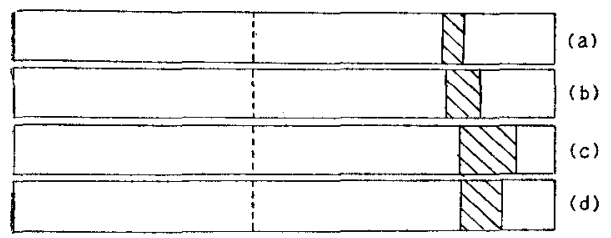

(a) $\mathrm{pAg} 2$, 電压 $500 \mathrm{~V}$ ，通電時間 33 分

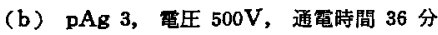

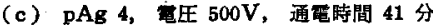

(d) pAg 5, 㫣正 $500 \mathrm{~V}$, 通電時間 50 分

因 10 グフニジンの口紙電気泳動の $\mathrm{pAg}$ 变化 (pH 5)
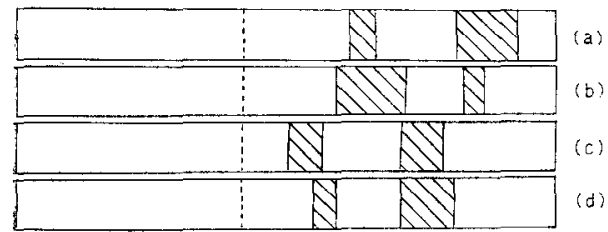

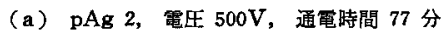

(b) pAg 3, 電压 $500 \mathrm{~V}$, 通电時間 56 分

(c) pAg 4, 電压 $500 \mathrm{~V}$, 通電時間 50 分

(d) $\mathrm{pAg} \mathrm{5}$, 電压 $500 \mathrm{~V}$, 通電時間 55 分

図 11 ベンザルアセトングアニルヒドラゾンの 口紙電気泳動の $\mathrm{pAg}$ 変化 ( $\mathrm{pH} \mathrm{5)}$

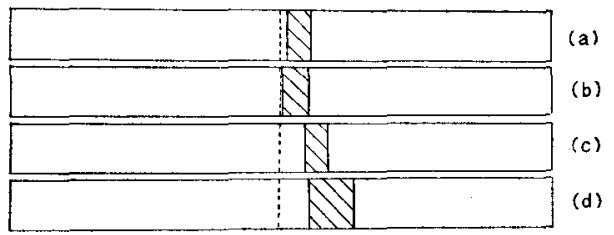

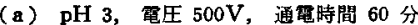

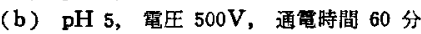

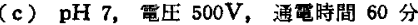

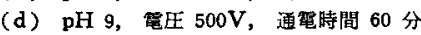

图 12 過酸化水素の口紙電気泳動の $\mathrm{pH}$ 変化 (pAg 3)

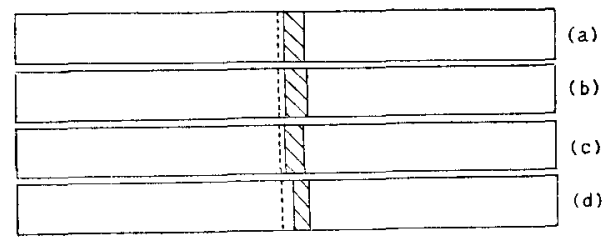

(a) $\mathrm{pAg} 2$, 電压 $500 \mathrm{~V}$, 通電時間 60 分

(b) $\mathrm{pAg} 3$, 電圧 $500 \mathrm{~V}$, 通电時間 60 分

(c) $\mathrm{pAg} 4$, 電生 $500 \mathrm{~V}$, 通電時間 41 分

(d) $\mathrm{pAg} \mathrm{5,} 500 \mathrm{~V}$ ，通電時間 60 分

図 13 過酸化水素の口紙電気泳動の $\mathrm{pAg}$ 変化 $(\mathrm{pH} \mathrm{5})$

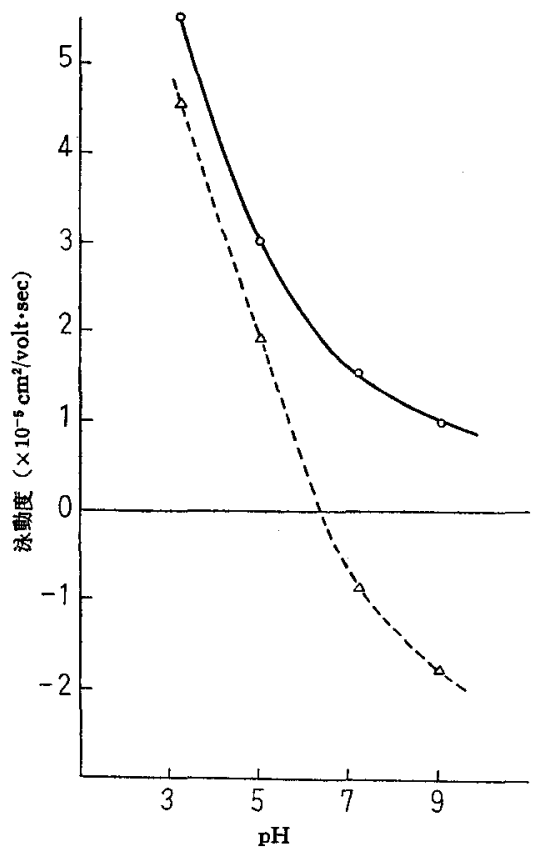

実線は補正前のもの 点線は補正後のもの

四 $14 \mathrm{pAg}$ をろに固定したときのチオ尿素の口紙 電気泳動度の $\mathrm{pH}$ による变化 


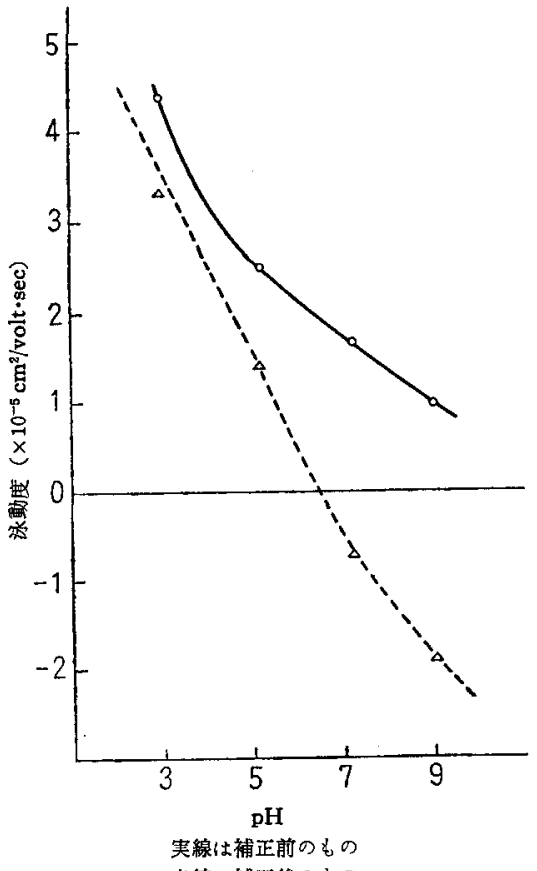

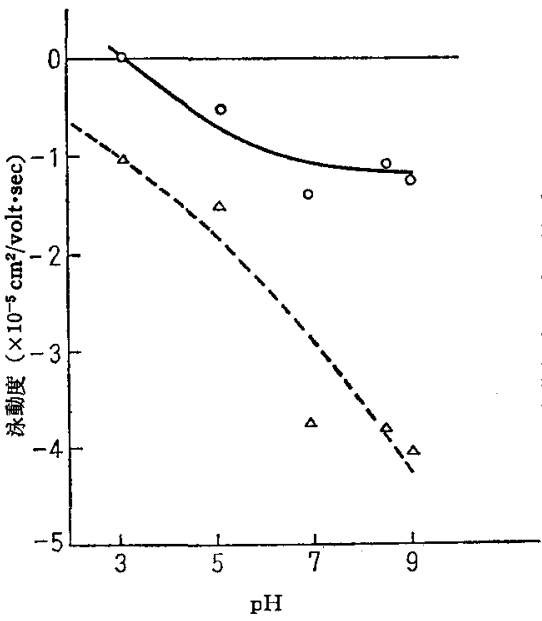

実線位補正前のもの

点線は補正後のもの

図 16 pAg 党 3 に固定したときの pーサクシ ノイルオミノベンッフルデヒド-3-チ オセミカルパゾンの紙電気泳動度の $\mathrm{pH}$ による変化

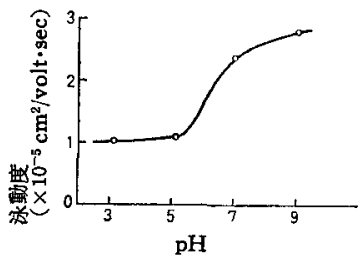

図 $19 \mathrm{pAg} 3$ に固定したと

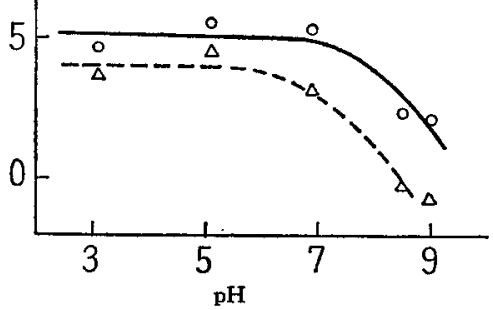

実線は補正前のもの

点線は補正後のもの

図 $18 \mathrm{pAg}$ を 3 に固定したときのベソザル フセトングアニルヒドラゾンのロ紙電 気泳動度の $\mathrm{pH}$ による变化 きの過酸化水素の口紙 電気泳動度の $\mathrm{pH}$ によ る变化

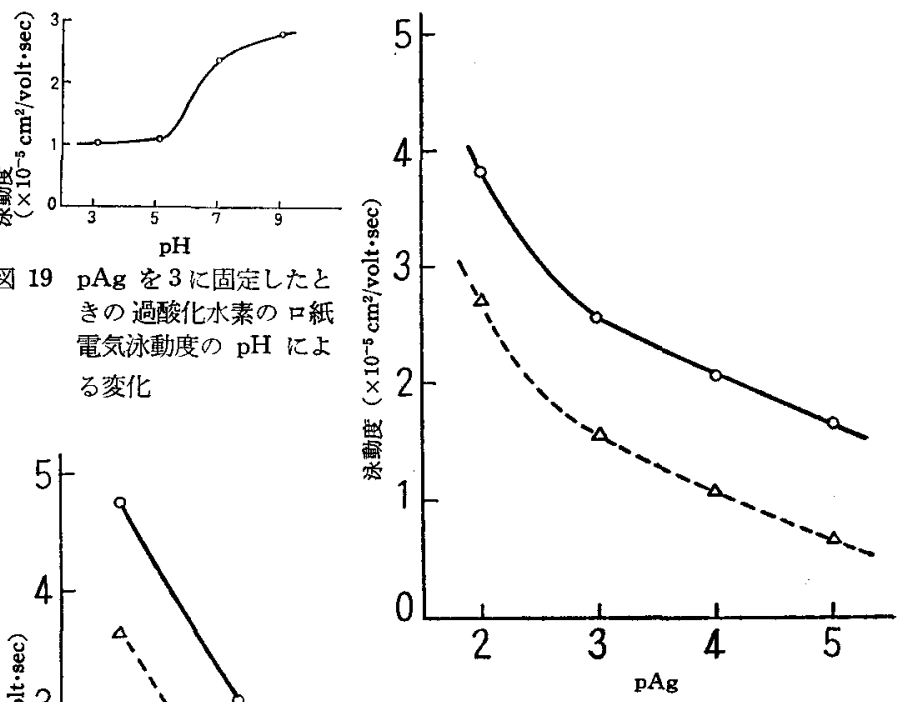

実線は補正前のもの

点線は補正後の无の

图 $21 \mathrm{pH}$ を 5 亿固定したと きのチオセミカルバジドの 口紙電気泳動度の pAg に よる変化

2

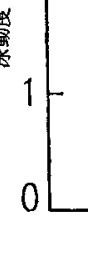

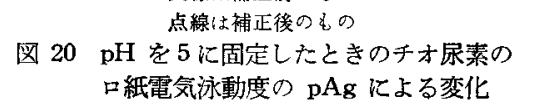




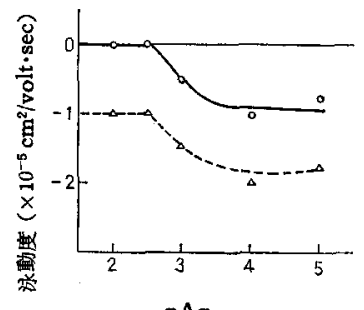

pAg 点楾法補正後のむの

図 $22 \mathrm{pH}$ 崖 5 に固定したとき のp-サクシノイルアミノ ベンツアルデヒドー3ーチオ セミカルバゾンの 口紙電 気泳動度 変化

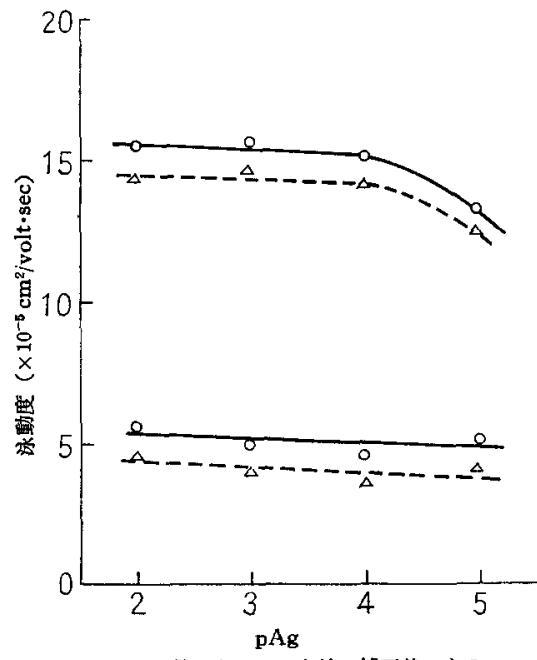

実線は補正前のもの 点線は補正後のもの

図 $24 \mathrm{pH}$ を 5 に固定したときのベソザルアセト ソグフニルヒドラゾンのロ紙電気泳動度の pAg による変化

$v=\frac{l}{t} / \frac{V}{30}\left(\mathrm{~cm}^{2} / \mathrm{sec} \cdot\right.$ volt $)$

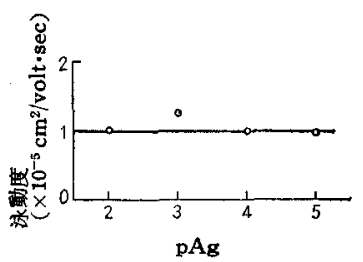

図 $25 \mathrm{pH}$ をに固定したとき の過酸化水菜の口紙電気 泳動度の $\mathrm{pAg}$ による变 化
実線は補正前のしの

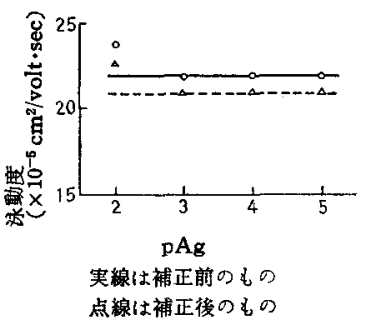
きのグフニジンのロ紙 電気泳動度の $\mathrm{pAg} に$ よる変化
图 $23 \mathrm{pH} 5$ に固定したと

匈をプロットして画いたものであり，点線は電気浸透現 象を考虑に入れた補正值である。

電気浸透現象の测定は常法 ${ }^{2}$ に従い過酸化水素を用い て行なった．銀イオンを含む緩衝溶液中の過酸化水素の 見掛け泳動势らびに泳動度の $\mathrm{pH}$ あるいは $\mathrm{pAg}$ 変化 の模様はそれぞれ図 $12,19,13$ および図 25 に示して ある。

図 18 と 24 には実線，点線ともに二本づつあるが， これは図6ならびに図11 からもみられるようにベンザ ルアセトングアニルヒドラソンンの移動帯が二成分に分離 したのでその二成分につき各泳動度を示したためであ る.図6 ならびに図 11 に扔いては示してないがベンザ ルアセトングアニルヒドラゾンにはてれら二本の帯のほ 中央に移動性を示さ白色沈殿物を認めた。乙れらは発 か，色しなかった。

\section{7 結 果 解 析}

図 2〜11 を注意深く観察すると各試料の口紙泳動性 について次のような特徴が兒いだされる。

チオ尿素わよびチオ七々カルバジト

（イ）一定 pAg 下で沬 pH の低いほど移動带の幅 が広く，pH の高いほど移動帯の幅が狭くなる頓向にあ る*.

（口）一定の $\mathrm{pH}$ 下では $\mathrm{pAg}$ の低いほど移動带の 幅が広く，pAg の高いはど移動带の幅が狭くなる傾问 にある。

（八）高 $\mathrm{pH}$ 側では口紙がカッ色一黒色状に着色す る. $\mathrm{pH}$ の高いはど着色の度合が大きい．

（二）との着色の度合は pAg が低いほど大きい。

p-サクシノイルアミノベンツー3-チオセミカルバゾン

(イ）一定 pAg 下では $\mathrm{pH}$ の低いほど移動带の幅 が狭く、 $\mathrm{pH}$ の高いほど移動带の幅が広くなる傾向にあ る。

（口）一定 $\mathrm{pH}$ 下では pAg の低いほど移動带の幅 が狭く, pAg の高いはど 移動帯の幅が広くなる傾向に ある

（八）低 $\mathrm{pH}$ では口紙が黄色状（試料自身の色調に 類似に着色する。中性またはアルカり性では最初から 着色は認めないが放置するにしたがって徐々にカッ色〜 黒カッ色状に変色する. pH 5 付近の場合が最も濃厚な 着色定示す、アルカリ性ではわずかに着色が認められる 程度である。

（二）との着色の度合は $\mathrm{pAg}$ の低いほど大きい，

グアニジンとベンザルアセトングアニルヒドラン゙ンに 関しては図 5,6,10 および図 11 における各実験の通電

* この㑯向は正しくは pH 3〜7に関してい5ベきかもしれない。 pH 7 の場合と pH 9 の場合を比較すると後者がやや幅広くなってい る. 
時間が異なるととを考虑に入れると移動帯の幅の大いさ と $\mathrm{pH}$ あるいは $\mathrm{pAg}$ の大いさとの関係については一 概に結論を下せない。ただしベンザルアセトングアニル ヒドラゾンについては二つの発色帯の内, 速性帯が遅速 性帯より一般に幅が広い傾向にあるのが注目される。

次に図 14〜18 および図 20〜24 から結論される事柄 は

（イ） p-サクシノイルアミノベンツ-3-チオセミカル バゾンを除き各添加剤は陽イオンとして行動する傾向が 強く硝酸銀の存在する場合も存在しない場合 ${ }^{1)}$ と同様に $\mathrm{pH}$ によって支配され酸性側では移動性が大きく，アル カリ性では移動が小さくなる．チ才尿素, チ才セミカル バジドのでときはある $\mathrm{pH}(5 \sim 7)$ より㓌イオン的とな る.

p-サクシノイルアミノベンツ-3-チ才セミカルバゾン のみは酸性でも中性分子的または陰イオン的でアルカリ 性では著しく陰イオン的となる。

以上の傾向はグアニシンの場合を除いてU字管電気泳 動法の結果とよく一致する ${ }^{3) ~ 6) . ~}$

(ロ ）添加剤の泳動度は pAg によっても影響をうけ ることがありチ才尿素, チ才セそカルバシドはその傾向 が著しい．てれに対し p-サクシノイルアミノベンッ-3チオセミカルバゾン，グアニジン，ベンザルアセトング アニルヒドラゾンはそれほど䫓著ではない．との傾向も U字管電気泳動性の結果とよく一致する

以上は緒論で触れたように，添加剤が水素イオンまた は銀イオンと結合を起とし陽性の錯イオンを生成すると いう考え方を強めるものである。すなわち,チ才尿素, チ オセミカルバジドは水素イオン, 銀イオンの存在下では これらと反灾して $\mathrm{A}_{l} \mathrm{H}^{+}{ }_{m}$ 型のほかに $\mathrm{A}_{l} \mathrm{H}^{+}{ }_{m} \mathrm{Ag}^{+}{ }_{n}$ 型 の錯イオンをつくる可能性が考えられる. その構造は本 実験からは結論を出すことはできないがす後に述べ るようにSを含ま欢グアニジンやベンザルアセトングア ニルヒドラゾンが銀イオンとの反応性が疑しいととから 考えて，たとえば銀イオンは $\mathrm{S}$ の部分と相互作用を持ち $\mathrm{Ag}^{+} \ldots \mathrm{SC}<（ ま た は ~ \mathrm{Ag}^{+} . . . \mathrm{SC} \ll ）$ と接近し $\mathrm{S}$ の不対電 子と配位結合をなして $[\mathrm{Ag}-\mathrm{SC}<]^{+}\left(\right.$または $\left.[\mathrm{Ag} ・ \mathrm{~S} K]^{+}\right)$ のごとき錯イオンになるのではないかと考えられる。と すると水素イオンは $-\mathrm{NH}_{2}$ (または $\left.=\mathrm{NH}\right)$ の $\mathrm{N}$ 部分 と同しく配值結合をなしててれも錯イオン形成にあづか ることが考えられる。

なおチオ尿素，チ才セミカルバジドがアルカリ性で陰 イオン的となるのは次のような互変異性を考慮に入れて 説明できる。

$$
\begin{aligned}
& \mathrm{SC}<\mathrm{NH}_{2} \mathrm{NH}_{2} \rightleftharpoons \mathrm{HSC}^{\prime} \mathrm{NH}_{2} \rightleftharpoons \mathrm{H}^{+}+\left[\mathrm{SC}-\mathrm{NH}_{2}\right]^{-} \\
& \text {(ケト型）(エノール型） }
\end{aligned}
$$

p-サクシノイルアミノベンツ-3-チ才セミカルバゾン は酸性下では難溶性沈殿物を生成して移動しがたいか， あるいは $\mathrm{NH}_{3}{ }^{+} \mathrm{RCOO}^{-*}$ のごとき電気的中性の状態に あるため移動しがたいと考えられるがアルカり性では $\mathrm{NH}_{2} \mathrm{RCOO}^{-}$となって陰性のイオンとなるので陽䓧の方 八移動性を示すものと考劣られる.銀イオンとの反応性 については銀イオンが濃厚になるといくぶん裁われてく るようにみえる。乙の場合も S の部分が関係しているの かもしれない。

グアニジンらびにベンザルアセトングアニルヒドラ ゾンは水素イオンと反灾して $\mathrm{A}_{l} \mathrm{H}^{+} m$ 型の陽性錯イオ ンをつくるととは前報》で述へたように十分考えられ る.しかしこれらは銀イオンと反応して $\mathrm{A}_{l} \mathrm{H}^{+}{ }_{m} \mathrm{Ag}^{+}{ }_{n}$ 型の生成する傎向は此較的弱いように思う**. 少なくと もグアニジルついてはてのことがいえると思う。ただ し $\mathrm{A}_{l} \mathrm{H}^{+}{ }_{m}$ と銀イオンとの交換による $\mathrm{A}_{l} \mathrm{Ag}^{+}{ }_{n}$ 型錯イ オンの形成は考光られぬとともない $\mathrm{A}_{l} \mathrm{H}_{n}{ }^{+}$形錯イオン と $\mathrm{A}_{l} \mathrm{Ag}^{+}{ }_{n}$ 形錯イオンの泳動度はイオンの大いさも電 荷数もはぼ同一と考学られるからである。しかしこの考 えは筆者ら の銀電位滴定の実験結果からは結局否定さ れる。

グアニジンはロ紙電気泳動の結果からは水素イオンに 敏感で, かように $\mathrm{A}_{l} \mathrm{H}^{+}{ }_{m}$ 型錯 イオンの生成の可能性 が推定されるにかかわらず，U字管電気泳動法では水素 イオンや銀イオンには敏感でなく，むしろかような傾向 が否定され気味であっだ゙. これは前報いでも述べたよ うにたとえばダアニジンそのものは $\mathrm{A}_{l} \mathrm{H}^{+}{ }_{m}$ 型錯イオ ンとなってもこのイオンが㚖化銀粒子に対して吸着性を ほとんど持たないからU字管法ではその影響が認められ なかったとして説明される（U字管法では臭化銀粒子 の移動を観測しているからら).

移動帯の幅の大いさと $\mathrm{pH}$ ならびに $\mathrm{pAg}$ との閪に は何らかの関連があるように思われる.少なくともとて で取り扱った $\mathrm{S}=\mathrm{C}<\mathrm{N} \mathrm{R}_{\mathrm{N}} \mathrm{R}_{\mathrm{j}}$ 型のものに関しては，陽 性の錯イオンをつくりやすいと思われるものでは低 $\mathrm{pH}$, 低 $\mathrm{pAg}$ であるほど幅広くなる傾向があり，陰性の錯イ オンをつくりやすいと思われるものでは逆に高 $\mathrm{pH}$ ，高 pAg であるほど愊広くなる傾向にあるというととがい えそうである。しかしその他の試料については前述の理 由で，今回の結果から同様のてとがいえるかどうかは疑 わしい.したがってててではこのような傾向のみられる

* $\mathrm{R}$ は本添加剂分子の $\mathrm{NH}_{2}, \mathrm{COOH}$ 基を除いた部分を総括的に示し ているものとする。

**ペンザルアセトンクアフルヒドラゾンに対するこの結諭は二つの移動 带に対していえるのであってこの督加剤にはさらに中央に全く移動し ない第三の带か認められている。(発色性のないもの)，このような白 沈性の物賈は銀イオンを含ま婸合には認められていないから敛化合 物々考克られる。こ机か移野性を認め奴のは陽錯イオンを形成すると

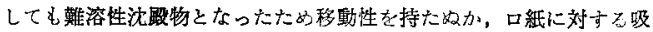
着性が强いためと考えられる。 
表 1 各添加用の推定されるイオン

（錯体を含さ）の型

\begin{tabular}{|c|c|c|c|c|c|}
\hline \multirow{2}{*}{ 試 } & \multirow{2}{*}{ 料 } & \multicolumn{4}{|c|}{ イオン（錯体を含む）の型 } \\
\hline & & $A^{-}$ & $\mathrm{A}_{l} \mathrm{H}^{+}{ }_{m}$ & $\mathrm{~A}_{l} \mathrm{H}^{+}{ }_{\mathrm{Ag}^{+}{ }_{n}}$ & $\mathrm{~A}_{l} \mathrm{Ag}^{+}{ }_{n}$ \\
\hline I & $\begin{array}{l}\text { 酸 性 } \\
\text { アルカリ性 }\end{array}$ & 0 & 0 & 0 & \\
\hline II & $\begin{array}{l}\text { 酸 性 } \\
\text { アルカリ性 }\end{array}$ & 0 & $\mathrm{O}$ & 0 & \\
\hline III & $\begin{array}{l}\text { 酸 性 } \\
\text { アルカリ性 }\end{array}$ & 0 & $P$ (沈) & ? (沈) & ? (沈) \\
\hline IV & $\begin{array}{l}\text { 酸 性 } \\
\text { アルカリ性 }\end{array}$ & & $\begin{array}{l}0 \\
0\end{array}$ & $\begin{array}{l}x \\
x\end{array}$ & \\
\hline $\mathrm{V}$ & $\begin{array}{l}\text { 酸 性 } \\
\text { アルカリ性 }\end{array}$ & & $\begin{array}{l}0 \\
0\end{array}$ & $\begin{array}{l}0 \\
0\end{array}$ & \\
\hline
\end{tabular}

(注) 試料番号は緒論に記載したもの

$\mathrm{A}^{-}$は添加剂の解㒕した状態を示す $\left(\mathrm{A} \rightleftharpoons \mathrm{A}^{-}+\mathrm{H}^{+}\right)$,

○印は存在が推定されること， $\times$ 印は存在が否定されること，？

印は存在が考えら机るもな疑わしいこと，沈は沈降性なることを

示す。空欄はをの存杏について十分検討されていないのて記載しな

いままになっている。

理由については議論を暫く保留したい，さらに多くの試 料について実験を試みた上で改めてての問題について考 えてみたいと考えている。

ベンザルアセトングアニルヒドラゾンは 2 はし 3 成
分に分離したことは錯体生成反応は単純でないととを示 している.その他の試料単一な移動带しか見いだされ ていないがてれからてれらの試料の錯体生成反応は単一 なものとただちに断定するのはなお危除なように思われ る.幅広い移動帯を示すものは数種の錯イオンの重畳し ている可能性も考光られるからである.

\section{8 総括}

以上を総括して筆者らは本研究からその具体的構造は ともかくとして各添加剤は表 1 亿示すでとき各種の錯体 生成の可能性あるととを推論するるのである．

終りに臨み本研究の実施に際し測定装置の便宣を与元 られた小西六写真工業に厚く感謝の意を表する。

(昭 39-4-28 受理)

\section{文献}

1）鈴伸木，高橋涉，本誌 32，589（1964）.

2) 菅野浩, 化学の領域 14 (No.5), 54 (1960).

3）铃木伸，大石恭史，工化 66, 887 (1963).

4) 鈴木伸, 工化 66, 1751 (1963).

5）跲木伸, 渡辺希美, 日写 26, 27 (1963)

6) 鈴木伸，平田明，本誌 32，347 (1964).

7) 鈴木伸, 古関靖夫, 分析化学 12,623 (1963).

\section{酸化体のみ含まれた系の西㥛反応における定電流法による 速度論的取り扱いについで}

\section{Galvanostatic Determination of Kinetic Parameters of Electrode Reaction with Generation of A Reactant in Situ.}

外島忍㴧, 沖中裕***, 岡庭宏** Shinobu Toshima Yutaka Okinaka Hiroshi OKaniwa

\section{1 緒言}

われわれ牥，酸化体のみ測定系中に含まれ還元体は電 颠反応によって電極上に生成される場合について，さき に定電位法による理論的取り扱いを試み，解析方法を明 らかにしだ。本報文は，定電流法による同様な理論的 取り报いを試みんとするものである。

Berzins, Delahay ${ }^{2)}$ にってはじめられた定電流法に おいては，酸化体および還元体の両方が，最初から測定 系中存在していることを必要とした。したがって， 溶液中またはアマルガム中の還元体 (Red.たと元ば $\mathrm{Zn}(\mathrm{Hg}), \mathrm{Cu}(\mathrm{Hg}))$ が, 非常に反応性にとみ酸化されや すい場合，反応系を安定に保持する点で実験がむずかし

\footnotetext{
*䇴気化学協会第 31 回大会（昭和 39 年 4 月）九州にて講演

** 東北大学工学部空用化学科 (宮城県仙台本楼小路)

*** ヘル電話研究所 (Whippany, New Jersey, U.S.A.)
}

くなる.さらに，酸化体および還元体の両方が，最初か ら測定系中に存在している一すなわち平衡電位が与兄ら れる系一に限られるため，ての適用範囲がせばめられ る. 一方，定電流で分極して得られる電位一時間曲線を 解析する際，電位領域は平衡電位近傍であるととが望ま しいととを考えれば，速い反応はぞ，その電位変化が短 い時間領域内に入るので，実験条件は厳しくなる。

これ视して，わ刘わ机は，測定系中に酸化体のみ含 まれる系 (自然電位が与えられる系) を定電流で分極し て得られる電位一時間曲線について，一定の電位軸を切 る電流上時間の関係から，電流を電流入(時間) $)^{1 / 2}$ でプ ロットすると直線になるととを理論的に見いだした。こ れより電流 $\times(\text { 時間 })^{1 / 2}$ を零に外えうして得られる 初期 電流，ならび代との直線の傾斜加ら右向き，左向きの遗 度定数を知って，それらの対数を電位に対してプロット して得られる直線加ら種々の電極反応の速度論的パラメ 